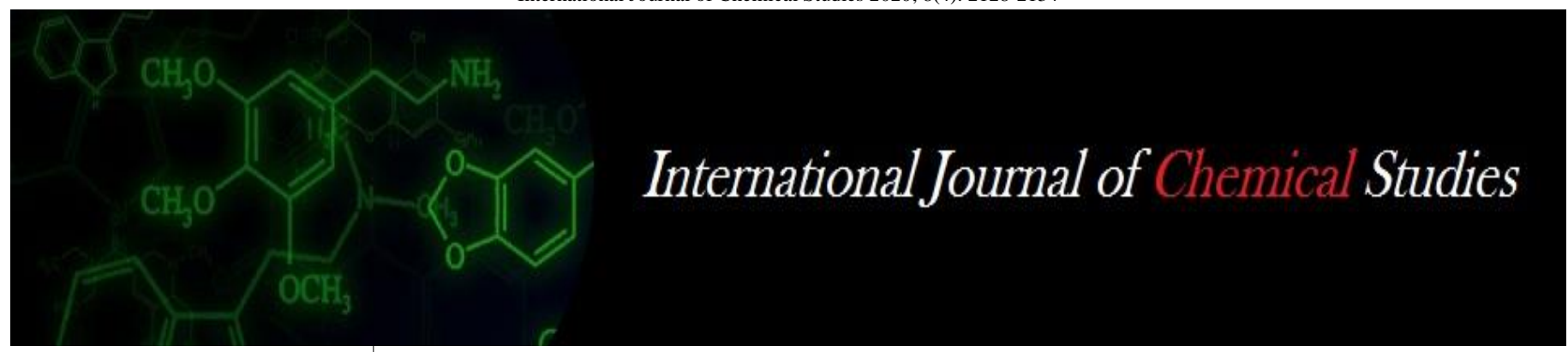

P-ISSN: 2349-8528

E-ISSN: 2321-4902

www.chemijournal.com

IJCS 2020; 8(4): 2128-2134

(C) 2020 IJCS

Received: 15-05-2020

Accepted: 17-06-2020

\section{KM Desai}

P. G. Scholar, College of

Horticulture, S. D. Agricultural

University, Jagudan, Mehsana,

Gujarat, India

\section{AR Patel}

P. G. Scholar, College of

Horticulture, S. D. Agricultural

University, Jagudan, Mehsana,

Gujarat, India

\section{Piyush Verma}

Associate Professor \& Head, Department of Horticulture,

C. P. College of Agriculture,

S. D. Agricultural University,

Sardarkrushinagar, Gujarat, India

\section{Mukesh Kumar}

Assistant Professor, College of

Horticulture, S. D. Agricultural

University, Jagudan, Mehsana,

Gujarat, India
Corresponding Author: KM Desai

P. G. Scholar, College of Horticulture, S. D. Agricultural University, Jagudan, Mehsana, Gujarat, India

\section{Transgenic vegetables: A new horizon}

\author{
KM Desai, AR Patel, Piyush Verma and Mukesh Kumar
}

DOI: https://doi.org/10.22271/chemi.2020.v8.i4w.9942

\begin{abstract}
Vegetables are grown worldwide and play an important role in human diets because they provide vitamins, minerals, dietary fiber and phytochemicals. Asia produces and consumes more than $70 \%$ of the world's vegetables. Their production and consumption are rising due to increase in consumer's income. Vegetables are also associated with improvement of gastrointestinal health, good vision, and reduced risk of heart disease, stroke, chronic diseases such as diabetes, and some forms of cancer. The consumption and caloric contribution of vegetables to the diet vary widely with geographical region, nationality, local customs and cuisine. Vegetable production suffers from many biotic stresses caused by pathogens, pests, and weeds and requires high amounts of plant protection products per hectare. US vegetables farmers are benefiting from growing transgenic squash cultivars resistant to Zucchini yellow mosaic virus, Watermelon mosaic virus, and Cucumber mosaic virus, which were deregulated and commercialized since the mid-1990s. Bt-sweet corn has also proven effective for control of some lepidopteran species and continues to be accepted in the fresh market in the United States, and Btfresh- market hybrids are released each year. Likewise, transgenic $B t$-eggplant was bred to reduce pesticide use and hopefully will soon be grown by farmers in Asia. There are other vegetable crops in the pipeline that have been genetically modified to enhance their host plant resistance to insects and plant pathogens (including viruses), to show herbicide tolerance, and to improve features such as slow ripening that extends the shelf-life of the produce, high nutritional status, seedless fruit, and increased sweetness. Transgenic plant breeding therefore provides genetically enhanced seed embedded technology that contributes to integrated pest management in vegetable production by reducing pesticide sprays as well as improving food safety by minimizing pesticide residues. Furthermore, herbicide-tolerant transgenic crops can help reducing plough in fields, thereby saving fuel because of less tractor use, which also protects the structure of the soil by reducing its erosion. Transgenic vegetable crops could make important contributions to sustainable vegetable production in this 21 st century. However, countries vary in their market standards of acceptance of transgenic crops. Biotechnology products will be successful if clear advantages and safety are demonstrated to both growers and consumers.
\end{abstract}

Keywords: Bio safety, GM crops, Horticulture, Virus, Biotechnology, plant breeding and Transgenic

\section{Introduction}

Horticulture production in india is currently about 307 million tons from area of 24 million hectare (Anony. 2018) ${ }^{[2]}$ and horticulture production has surpassed the food production in the country since 2012 . It has proven beyond doubt that productivity of horticulture crops is much higher as compared to the productivity of food grains. Vegetable and fruit consumption is rising in India enormously, reflecting the consumer's increased income, desire of diversity and health awareness among the masses.

Vegetables supply essential vitamins, minerals, dietary fiber and phytochemicals to human diets. Some phytochemicals of vegetables are strong antioxidants and seem to reduce the risk of chronic disease by protecting against free radical damage by modifying metabolic activation and detoxification of carcinogens or even by influencing processes that alter the course of tumor cells. At least half of the preschool children and pregnant women are affected by micronutrient deficiencies in Bangladesh, Cambodia, Nepal and the Philippines (Helen Keller International 2010) ${ }^{[8]}$. Vegetables contain a range of macro and micronutrients including provitamin $\mathrm{A}$, iron and zinc, which contribute to the prevention of malnutrition disorders. Small variation in maternal diets particularly reduction in micronutrient content, can have a significant impact on fetal growth and development. Pregnant women in particular benefit from good vegetable nutrition during later pregnancy and lactation. 
The interplay of the different micronutrients and antioxidants found in vegetables has important health impacts in Instance the higher birth weight of children in India, when mothers consumed higher rates of green leafy vegetables and fruits during pregnancy (Rao et al. 2001) ${ }^{[19]}$. Diets rich in vegetables, in all their many forms ensure an adequate intake of most micronutrients, dietary fibers, and phytochemicals which can bring a much-needed measure of balance back to diets contributing to solve many of these nutrition problems.

Vegetables are grown worldwide on large and small farms, on good and marginal lands, in urban and rural areas and by large commercial growers and small subsistence farmers. Short production cycle vegetables allow multiple cropping and a significant volume of the vegetables grown worldwide are produced in small plots, which makes difficult to estimate accurately their production, thereby preventing a clear understanding and appreciation of the value of these crops to the world food supply. The main reason for this increase was the rapid growth in mean per capita incomes, and awareness of nutritional benefits. A world vegetable survey showed that 402 vegetable crops are cultivated worldwide, representing 69 families and 230 genera. Leafy vegetables of which the leaves or young leafy shoots are consumed- were the most often utilized $(53 \%$ of the total), followed by vegetable fruits $(15 \%)$, and vegetables with below ground edible organs comprised $17 \%$. Many vegetable crops have more than one part used. Most of the vegetables are marketed fresh with only a small proportion processed because most vegetables are perishable. Consumption shortly after harvest guarantees optimal vegetable quality. Only $67(17 \%)$ of commercial vegetables have attracted investments for crop breeding by multinational seed corporations, due to their large area of production and substantial consumption, $52(13 \%)$ vegetables were considered minor, and other $87(22 \%)$ species were considered rare.

Global commercial vegetable seed sales had an annual growth rate of $5.8 \%$ in the last decade (Dias, 2011) ${ }^{[5]}$. Vegetable production suffers from many biotic stresses caused by pathogens, pests, and weeds and requires high amounts of pesticides per hectare. Pest loads vary and are complex visàvis field crops because of the high diversity of vegetable crops and due to their cultivation intensity. The main method for controlling pathogens, pests, and weeds has been the use of pesticides because vegetables are high-value commodities with high cosmetic standards. Synthetic pesticides have been applied to vegetable crops since the 1950s, and have been highly successful in reducing crop losses to some insects, pathogens and weeds. Vegetables account for a significant share of the global pesticide market. About $20 \%$ of the world's annual pesticides expenditures (amounting to US\$ 8.1 billion) are spent for growing vegetables (Krattinger 1998) ${ }^{[12]}$. Insecticides are regularly applied to control a complex of insect pests that cause damage by feeding directly on the plant or by transmitting pathogens, particularly viruses. Despite pesticide use effect oninsects, pathogens, and weeds continue to cause a heavy toll on world vegetable production. Preharvest losses are globally estimated as $15 \%$ for insect pests, $13 \%$ for damage by pathogens and about $12 \%$ for weeds. Pest and viruses are particularly important in tropical and subtropical countries like many of Southeast Asia. Pesticide residues can affect the health of growers and consumers and contaminate the environment. Vegetables are often consumed in fresh form, so pesticide residue and biological contamination is a serious issue. Consumers worldwide are increasingly concerned about the quality and safety of their food as well as the social and the environmental conditions under which it is produced. Vegetable prices will therefore increase by enhancing their quality and safety.

Biotechnology is a new powerful tool that has been added in most of the horticultural crop breeding programs and genetically modified plants are the results of modern biotechnology. Transgenic crops commonly referred to as genetically modified (GM) crops enable plant breeders to bring favorable genes often previously inaccessible into elite cultivars improving their value considerably and offer unique opportunities to overcome important problems of modern agriculture like plants with improved agronomic traits, resistance to biotic and abiotic stresses, tolerance to herbicides \& enhanced nutritional quality.

Genetic transformation can introduce a gene for desired trait without disturbing the plant genetic architecture and also can be introduced directly into the host organism or into a cell. Thus, transgenic food plants and their products should make agriculture based food production more successful and productive (Khachatourians et al., 2002) ${ }^{[11]}$. About 18 million farmers in 24 countries grow GM crops over 189.8 million ha (Anony 2017) ${ }^{[1]}$. More than half of the GM crop cultivated in the United States followed by Argentina, Brazil, Canada, China, Paraguay and India (Singh et al., 2017) ${ }^{[22]}$.

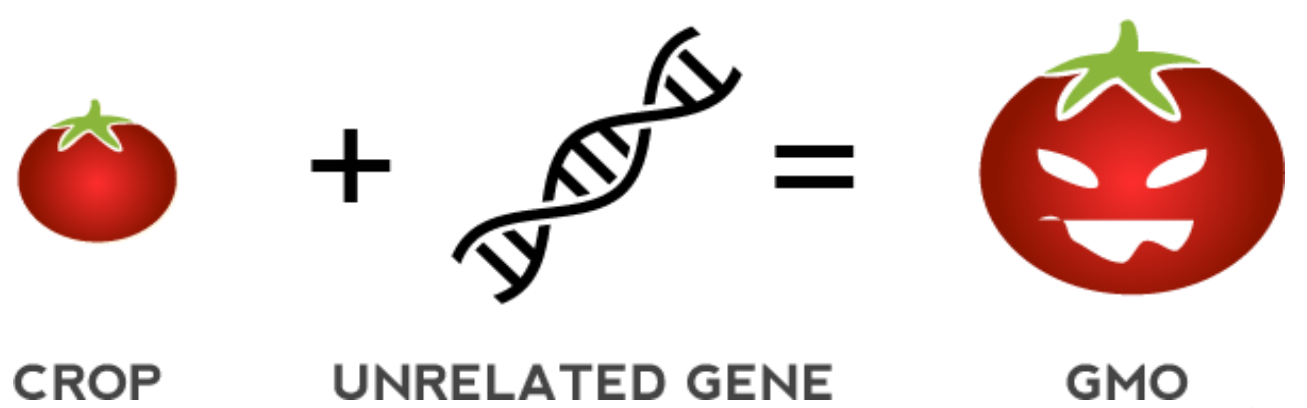

Source: ISAAA (2017)

\section{Status of Trangenic crops - World}

- Transgenic plants were first created in the early 1980s by four groups working independently at Washington University in St. Louis in Tobacco by schell and Montago.
- First commercialized crop introduced was Flavr Savr tomato in USA in 1994.

- Major characteristics are insect resistance, herbicide tolerance, virus resistance and improved product quality.

- About 18 million farmers in 24 countries grow GM crops over 189.8 million ha areain 2017. 


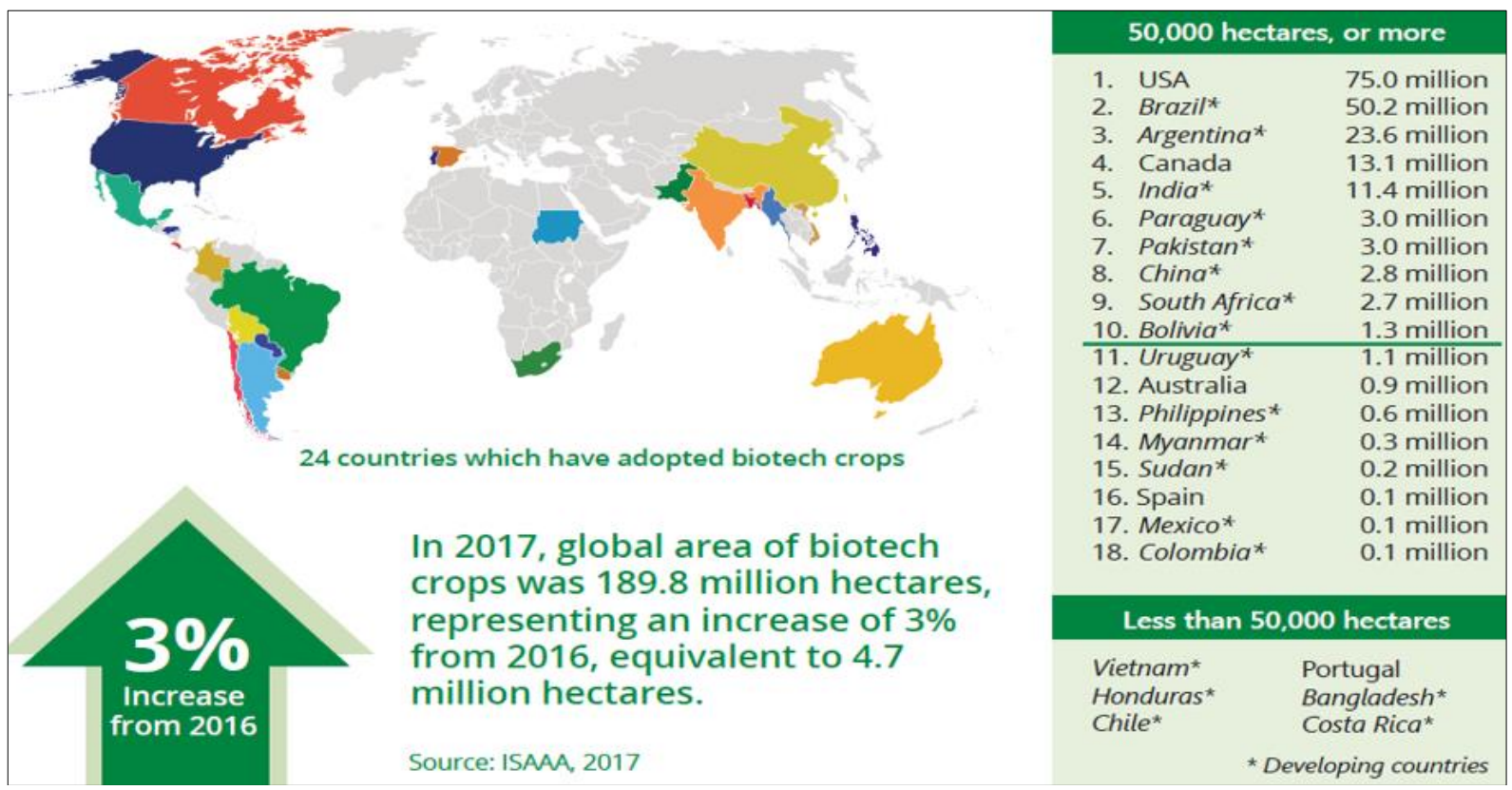

Source: Anuual Biotech crops, ISAAA (2017)

Fig 1: Biotech Crop Countries: 2017

\section{Genetic enhancement of vegetables}

Vegetable breeding must include improving nutrition value because they are very important for human health (Dias and Ryder 2011) ${ }^{[5]}$. Historically vegetable breeders have applied selection pressure to traits related to agronomic performance, particularly yield and quality, because these are the traits important to the producers. Growers have seldom been recompensed for nutritional factors, so there have been no economic incentives to provide significant attention to these traits. However, consumers are becoming more aware of these traits. Genetic improvement to increase levels of specific micronutrients is complex because there is often a large environmental effect, when the component is present in tiny amounts. Success in vegetable breeding for higher vitamin and mineral content should consider not only substance concentration but also organic components in plants that can either reduce or increase bioavailability (Frossard et al., 2000) [7]. Enhanced nutritional content would add value for poor, malnourished populations. Breeding for pro-vitamin A, carotenoids, iron and zinc is of keen interest as a bio fortification strategy to alleviate nutrient deficiencies in developing countries. Transgenic crops, commonly referred to as genetically modified (GM) crops enable plant breeders to bring favorable genes often previously inaccessible into already elite cultivars for improving their value considerably and offer unique opportunities for controlling insects, viruses and other pathogens as well as nutritional quality. Conventional plant breeding that utilizes non-transgenic approaches will remain the backbone of vegetable genetic improvement strategies. However, transgenic crop cultivars should not be excluded as products capable of contributing to more nutritious and healthy food. Many vegetable crops have been genetically modified to include resistance to insects, pathogens (including viruses), herbicides and for improved features such as slow ripening, higher nutritional status, seedless fruit, and increased sweetness. Recently, (Dias and Ortiz 2012) ${ }^{[4]}$ did an analysis of the status (until 2010) of transgenic tomato, eggplant, potato, cucurbits, brassicas, lettuce, alliums, sweet corn, cowpea, cassava, sweet potato, and carrots. The most promising traits to reach vegetable growers seem to be host plant resistances to insects and other pathogens, especially for tomato, potato, eggplant, summer squash and sweet corn.

Table 1: The GM-vegetables already grown by farmers are in below

\begin{tabular}{|c|c|}
\hline Crop & Genetically Altered Traits \\
\hline Tomato & Delayed ripening: Antisense technology. \\
\hline Brinjal & Cry1Ac: resistance to brinjal shoot and fruit borer. \\
\hline Soybean & Resistance to glyphosate for control of weeds. \\
\hline Potato & $\begin{array}{c}B t \text { gene incorporated (Colorado potato beetle } \\
\text { resistant): Cry IIIgene from Bt. }\end{array}$ \\
\hline Squash & $\begin{array}{c}\text { Resistance to viruses: Coat protein genes of } \\
\text { watermelon mosaic virus. }\end{array}$ \\
\hline $\begin{array}{c}\text { Carnation, Petunia } \\
\text { and Rose }\end{array}$ & $\begin{array}{c}\text { Delayed senescence (carnation) and modified } \\
\text { flower colour. }\end{array}$ \\
\hline Papaya & Virus resistance \\
\hline
\end{tabular}

After the commercialization of the first transgenic vegetable in 1994 (Flavr Savr ${ }^{\text {TM }}$ tomato) for delaying fruit ripening and further research conducted to manipulate fruit ripening, texture and nutritional quality using transgenic approaches. Farmers in the United States are benefiting from growing transgenic squash cultivars resistant to virus, which were deregulated and commercialized since the mid-1990s. Engineered resistance has been so far the only approach to breed squash cultivars with multiple sources of resistance to ZYMV, WMV, and CMV (Schulteis and Walters 1998) ${ }^{[20]}$. Virus-resistant transgenic squash has allowed growers to achieve yields comparable to those obtained in the absence of viruses with a net benefit of US\$ 22 million in 2005 (Shankula 2006) ${ }^{[21]}$. Btsweet corn introduced commercially in 1998 which has also proven effective for control of some lepidopterous species and continues to be accepted in the fresh market in the United States and Btfresh-market hybrids are released each year (Dias and Ortiz 2012) ${ }^{[4]}$.

Transgenic Bt-eggplant has been bred to provide Asian farmers with cultivars showing host plant resistance to fruit and shoot borer (FSB), thereby reducing today's insecticide spraying during the crop season 40-80 times in India and more than 50 times in the Philippines (Choudhary and Gaur 2009) ${ }^{[3]}$. This Bt-eggplant was effective against FSB with $98 \%$ insect mortality in $B t$-eggplant shoots and $100 \%$ in fruits compared to less than $30 \%$ mortality in non- $B t$ counterparts 
(ISAAA 2008) ${ }^{[10]}$. An expert committee was setup in India to examine biosafety issues and data regarding $B t$-eggplant in 2006. They initially indicated that $B t$-eggplant was safe and equivalent to its non $B t$-counterpart but more research and trials were still needed to confirm these findings and ascertain its benefits regarding existing methods for pest management and for reducing pesticide use. In 2009 a second expert committee examined the data from these new trials and concluded that benefits of the available Bt-eggplant outweighed the perceived and projected risks, thereby advising the Genetic Engineering Appraisal Committee (GEAC) to recommend its commercialization in India. The GEAC cleared Bt-eggplant for commercialization in October 2009 but the Government of India officially announced in February 2010 that more time was needed before its release to farmers due to the successful lobbying made by antitransgenic crop activists. The Minister of Environment stated that this moratorium for growing $B t$-eggplant in India will remain until reaching a political, scientific and societal consensus. Recently, Brazil announced the beginning of field testing of a transgenic bean resistant to Golden mosaic virus, which is transmitted by whitefly and causes up to $85 \%$ yield loss, and will benefit both producers and consumers Beans are produced mainly by small growers and are the main source of vegetable protein, iron and many vitamins in Brazil and Africa.

Consumers could benefit further from eating more nutritious transgenic vegetables, e.g. an increase of crop carotenoids by metabolic sink manipulation through genetic engineering appears feasible in some vegetables. As stated vegetables offer also consumers a diverse mixture of nutrients that promote human health more beneficially than dietary supplements. However, the ingestion of plant-based diets rather than diets that rely primarily on animal products could limit the intake of essential nutrients such as calcium (Ca). Consequently, genetically engineering vegetables containing increase $\mathrm{Ca}$ levels may boost $\mathrm{Ca}$ uptake, thereby reducing the incidence of $\mathrm{Ca}$ deficiencies such as osteoporosis. In this regard, Park et al. (2004) ${ }^{[18]}$ modified carrots to express increased levels of the plant $\mathrm{Ca}$ transporter $s C A X 1$. These carrot lines were fertile and displayed no adverse phenotypes. Further mice and human feeding trials demonstrated increased $\mathrm{Ca}$ absorption from $s C A X 1$-expressing transgenic carrots vis$a$-vis controls (Morris et al. 2008) ${ }^{[16]}$. This research supports alternative means of bio fortifying vegetables with bioavailable $\mathrm{Ca}$. Zinc is also an essential element in human nutrition, as its deficiency severely impairs organ function. In experiments to fortify lettuce with this element, Zuoet al. $(2002)^{[24]}$ used Agrobacterium-mediated gene delivery of a mouse metallothionein mutant $\beta$-cDNA in the cv. 'Salinas 88'. The concentration of zinc in the transgenic plants increased to $400 \mu \mathrm{g}-1$ dry weight, which is considerably higher than in wild-type plants. Folate deficiency -regarded as a global health problem, causes neural tube defects and other human diseases. Foliates are synthesized from pteridine, $p$ aminobenzoate (PABA) and glutamate precursos. Diaz de la Garza et al. $(2004,2007)^{[6]}$ developed trangenic tomatoes by engineering fruit-specific overexpression of GTP cyclohydrolase I that catalizes the first step of pteridine synthesis and amynodeoxychorismate synthase that catalyzes the first step of PABA synthesis. Vine-ripened fruits contained on average 25-fold more folate than controls by combining PABA- and pteridine- overproduction traits through crossbreeding of transgenic tomato plants. The achieved folate level provides a complete adult daily requirement with less than one standard serving. Vitamin E which includes tocopherols- are lipid soluble antioxidants. There are $\alpha, \beta, \gamma$, and $\delta$ isoforms of tocopherol with relative vitamin $\mathrm{E}$ potencies of $100 \%, 50 \%, 10 \%$, and $3 \%$, respectively. Conversion of $\gamma$-tocopherol to $\alpha$-tocopherol in food crops could increase their value and importance in human health because vitamin $\mathrm{E}$ reduces the risk of several serious disorders (e.g. cardiovascular diseases and cancer), slows ageing and enhances the function of the immune system. Cho et al. (2005) [3] developed transgenic lettuce plants of the cv. 'Chungchima' expressing a cDNA encoding $\gamma$-tocopherol methyltransferase from A. thaliana to improve tocopherol composition. Transgene inheritance and expression in transformed plants increased enzyme activity and conversion of $\gamma$-tocopherol to the more potent $\alpha$ form. Similarly, resveratrol - a stilbenes - shows cancer chemopreventative activity and may prevent coronary heart disease and arteriosclerosis. Liu et al. (2006) ${ }^{[14]}$ in a quantitative analysis showed that resveratrol in transgenic lettuce plants was $56.0 \pm 5.52 \mu \mathrm{g}-1$ leaf fresh weight, which is comparable to that in the skin of grape fruit (Citrus $\times$ paridisi Macfad.).

Food safety can also be enhanced through transgenic approaches e.g. resource-poor people in rural Asia and Africa will benefit eating cyanide-free cultivars of cassava. Other experimental transgenic vegetables show host plant resistance to insects, nematodes, fungi, bacteria, and viruses, extended shelf-life of the produce, herbicide tolerance, enhanced nutritional status, seedless fruit and better flavor or can be used for vaccine delivery.

\section{Issues for transgenic vegetable breeding}

Breeding transgenic pest resistant vegetable cultivars can decrease management costs and release growers' time for other economic activities, while also contributing to a less toxic production environment. Transgenic vegetables with tolerance to abiotic stresses or enhanced input efficiency could also provide various benefits to farmers and the environment. Consumers could also benefit further from the use of more nutritious transgenic vegetables and food safety can be enhanced through transgenic approaches. Host plant resistance or product quality will increase the value of the vegetable throughout the chain, thereby benefiting farmers, traders and consumers. Genetic engineering has the potential to address some of the most challenging biotic and abiotic constraints faced by vegetables growers, which are not easily addressed through conventional plant breeding alone. However, horticulture remains in its infancy regarding the use of transgenic crop technology because vegetables are considered minor crops (compared to field crops), due to the lower resources invested (especially by the multinational private seed corporations) and derived of the high costs for deregulation. Most biotech research is done in field crops because multinational seed corporations expect the highest rate of return to their investment. While it is becoming less expensive to create transgenic crops for pest management, developing a marketable product and a regulatory package remains costly.

Development and regulatory costs can be recouped more readily if the product is grown on an extensive area (as happens with field crops), which is not generally the case for individual vegetable crops. The large multinational seed corporations have, for the most part, abandoned the development of transgenic vegetable crops because of the high costs associated with product development and deregulation. There are many cultivars of the same vegetable 
crop, and their expected life can be relatively short. Moreover, introducing a transgene into a breeding program can be complicated and cost prohibitive, especially in crops with difficulty for using backcrossing (e.g. cassava, potato or sweet potato). Furthermore, deregulation of a transgenic trait is event specific in many countries. It may not be therefore possible to develop a single transgenic event that can be converted into many different cultivars of a single or closely related group of vegetable species through conventional breeding.

\section{Transgenic vegetables and pest, virus and weed control}

Vegetables are grown worldwide mostly on smaller areas and in more diversified holdings than field crops such as cotton, canola, cereals and soybeans. Vegetables are often in more complex agricultural systems where insects may move from one crop to the next within the same farm. How this will impact the use and effects of transgenic vegetable plants in the agricultural landscape can be complex. Growing multiple insect-resistant transgenic vegetable plants in the same area and exposed of a polyphagous insect to the same $B t$ protein expressed in the different vegetable species will challenge conventional strategies developed for transgenic cotton or maize cultivars. Thoughtful consideration therefore will be needed before choosing what toxins vegetable plants should express. The selection should be based not only on what will be an effective toxin against the target insect but which toxins are already in use in other vegetable crops that may be hosts for the target insect. Additionally, the difficulty of sampling insect populations for resistant alleles will take on a higher level of complexity in a diversified vegetable system. Significant attention should also be given to the effects of transgenic vegetables on nontarget organisms. In this regard, Hoheisel and Fleischer (2007) [9] investigated the seasonal dynamics of coccinellids and their food (aphids and pollen) in a vegetable farm system containing plantings of $B t$-sweet corn, Bt-potato, and transgenic insect-resistant squash in northeastern USA. Their results indicated that the transgenic vegetable crops provided conservation of coccinellids and resulted in a $25 \%$ reduction in insecticide use. In a similar study with these same crops, Leslie et al. (2007) ${ }^{[13]}$ compared the soil surface dwelling communities of Coleoptera and Formicidae in the transgenic crops and their isolines and found no differences in species richness and species composition but found that the transgenic vegetables required fewer insecticide applications. Such results make clear that transgenic technology can be introduced within vegetable integrated pest management (IPM) systems and that transgenic vegetables can offer novel and effective ways of controlling insects and the pathogens they transmit. Such results make clear that transgenic technology can be introduced within vegetable integrated pest management (IPM) systems and that transgenic vegetables can offer novel and effective ways of controlling insects and the pathogens they transmit. Virus-resistant transgenic plants are particularly valuable if no germplasm source of resistance has been identified or if host plant resistance is difficult to transfer into elite cultivars by traditional breeding methods due to incompatibility barriers or links to undesired traits. In such cases, engineered host plant resistance may be the only viable option to develop virus resistant cultivars. Growers can also use virus-resistant transgenic vegetables as a trap crop by growing it as a border around the non- transgenic vegetable crop and allowing it to cleanse viruliferous aphids.

The challenges for regulatory oversight of transgenic plants are immense in small, diversified vegetable plantings, which are found throughout the developing world. In these countries, farmers will likely save transgenic seed and move transgenic seed between locations, and some transgenic products may move into markets that do not permit these products. These concerns will be lessened if people consume the produce from transgenic vegetables locally after they are released and grown following national biosafety guidelines. While each vegetable has its own set of one or more key pests, other pests can also be problematic. Traditional broad-spectrum insecticides often control a suite of pest insects. Thus, when transgenic vegetables are introduced into production systems, other methods of control will have to be applied or developed for secondary pests, e.g., biological control of secondary pests or use of selective insecticides, applied either as seed treatments or foliar sprays, may be necessary.

Integrated pest management could benefit from some herbicide-tolerant crops, if alternative nonchemical methods can be applied first to control weeds and the specific herbicide could be used later, only when and where the economic threshold of weeds is surpassed (Krimsky and Wrubel 1996). Herbicide-tolerant transgenic crops can help reducing plough in fields, thereby saving fuel because of less tractor use, which also protects the structure of the soil by reducing its erosion. Repeated use of herbicides in the same area may also create problems of weed herbicide resistance (Wrubel and Gressel 1994) ${ }^{[23]}$. Although the risk of herbicide-resistant genes in vegetables is globally lower than in field crops because many vegetables are consumed in the vegetative stage.

Table 2: Transgenic development in India

\begin{tabular}{|c|c|c|c|}
\hline Sr. No. & Crop & Organization & Transgene \\
\hline 1. & Brinjal & $\begin{array}{l}\text { IARI, New Delhi MAHYCO, Mumbai } \\
\text { Sungro Seed Research Ltd., New Delhi }\end{array}$ & $\begin{array}{l}\text { crylA } a \text { and } \text { crylAabc } \\
\text { crylAccrylAa }\end{array}$ \\
\hline 2. & Cabbage & Nunhems India Pvt. Ltd., Gurgaon & crylBa and $c r y l C a$ \\
\hline 3. & Castor & Directorate of Oilseeds Research (DOR), Hyderabad & crylAa and crylEc \\
\hline 4. & Cauliflower & $\begin{array}{l}\text { Sungro Seed Research Ltd., Delhi } \\
\text { Nunhems India Pvt. Ltd., Gurgaon }\end{array}$ & $\begin{array}{c}c r y l A c \\
\text { crylBa and } \operatorname{cry} l \mathrm{Ca}\end{array}$ \\
\hline 5. & Groundnut & ICRISAT, Hyderabad & Chitinase gene from rice (Rchit) \\
\hline 6. & Okra & MAHYCO, Mumbai & cry $1 A c$ and $c r y 2 A b$ \\
\hline 7. & Potato & CPRI, Shimla & $\begin{array}{c}\text { RB gene derived from Solanum } \\
\text { bulbocastanum }\end{array}$ \\
\hline 8. & Rice & $\begin{array}{l}\text { MAHYCO, Mumbai Tamil Nadu Agricultural University } \\
\text { (TNAU)IARI, Pusa New Delhi }\end{array}$ & crylAc and $c r y 2 A b$ rice chitinase (chi11) \\
\hline 9. & Tomato & IARI, Pusa New Delhi MAHYCO, Mumbai & $\begin{array}{l}\text { Antisense replicase gene of tomato leaf } \\
\text { curl virus cry } 2 A b\end{array}$ \\
\hline
\end{tabular}




\section{Outlook}

Vegetables are grown worldwide on large and small farms, on good and marginal land and by large commercial growers and small subsistence farmers. Transgenic cultivars could overcome some limiting factors in vegetable production, e.g., pathogens (bacteria, fungi, viruses), pests (insects and nematodes) and weeds. There is a major thrust at public sector R \& D institutes to develop GM crops. Nowadays, about 18 million farmers in 24 countries grow GM crops over 189.8 million haarea. Genetically Modified Agri - Horticultural crops have been developed for biotic resistance, increasing yield \& income, reduction in insecticide use, enriched nutrients, increased shelf life and they also helps in mitigating the effect of climate change. They could also help for reducing pesticide residues, human poisoning and reducing costs in horticulture. However, as noted by Ortiz and Smale (2007) ${ }^{[17]}$, before transgenic cultivars can be made available to vegetables farmers, particularly in the developing world several hurdles must be overcome. At this time, the most important of these appear to be related to intellectual property management, public awareness, biosafety guidelines, and food safety protocols. Appropriate measures needs to be sought to overcome such hurdles. The advantages of transgenic breeding should provide incentive for integration of this method into the amelioration of challenges for vegetables and horticultural production, if consumer fears are overcome or eased. The future of transgenic vegetables may be in the developing world, especially China and India, which account for $40 \%$ of the world population. Grow and consume in excess of $60 \%$ of the world's vegetables. They already adopted $B t$-cotton and it is likely that $B t$-rice will soon be reaching farmers in China. The acceptance of transgenic vegetables in both countries will likely hasten their adoption in other parts of the world and allow farmers to use these crops. Distinct perspectives leading to different policy options and standards may conflict with the current globalization market. Some policy options that may be appropriate for the developed world are sometimes inappropriate for the developing world. Transgenic crops are not a silver bullet for achieving food security but coupled with traditional knowledge and conventional agriculture may be a powerful tool for making available affordable food to poor farmers and consumers. Modern biotechnology can provide products with the potential for reducing farming costs, enhancing agricultural productivity, ensuring food supply, alleviating rural poverty, promoting sustainable use of natural resources, protecting the environment and preserving biodiversity. Biotechnology derived crops will succeed in farming systems if clear advantages and safety are demonstrated to both growers and consumers.

Our new century is predicted to be the "Century of Biology" as the last century was the "Century of Chemistry \& Physics". Now with modern biotechnology, farmers should play an increasingly more vital role in our economic prosperity. Ultimately, GM crops are still a relatively premature technology and in the developmental process. Only time will reveal their ultimate effect on human.

\section{References}

1. Anonymous. www.isaaa.org (International Service for the Acquisition of Agri-Biotech Applications), 2017.

2. Anonymous. www.nhb.org.in (National Horticulture Board), 2018.

3. Choudhary B, Gaur K. The Development and Regulation of $\mathrm{Bt}$ Brinjal in India. ISAAA Brief 38. International
Service for Acquisition of Agri- Biotech Applications, Ithaca, New York, 2009.

4. Dias JS, Ortiz R. Transgenic vegetable crops: progress, potentials and prospects. Plant Breed. Rev. 2012; 35:151246.

5. Dias JS, Ryder E. World vegetable industry: production, breeding, trends. Hort. Rev. 2011; 38:299-356.

6. Diaz de la, Garza RI, Quinlivan EP, Klaus SMJ, Basset GJC, Gregory JF. Folate biofortification in tomatoes by engineering the pteridine branch of folate synthesis. Proc. Natl. Acad. Sci. (USA). 2004; 101:13720-13725.

7. Frossard E, Brucher M, Mozafar A, Hurrell R. Potential for increasing the content and bioavailability of $\mathrm{Fe}, \mathrm{Zn}$ and $\mathrm{Ca}$ in plants for human nutrition. J Sci. Food Agr. 2000; 80:861-879.

8. Hellen Keller International. Homestead food production model contributes to improved household food security, nutrition and female empowerment - experience from scaling-up programs in Asia (Bangladesh, Cambodia, Nepal and Philippines). Nutrition Bulletin. 2010; 8:1-8.

9. Hoheisel GA, Fleischer SJ. Coccinelids, aphids, and pollen in diversified vegetable fields with transgenic and isoline cultivars. J Insect Sci. 2007; 7:64.

10. ISAAA. Bt Brinjal in India. Pocket $\mathrm{K} 35$. International Service for Acquisition of Agri-Biotech Applications, Ithaca, New York, 2008.

11. Khachatourians GC. Transgenic plants and crops. 1st ed. Canada, University of Saskatchewan., CRC Press, 2002.

12. Krattinger A. The Importance of Ag-biotech to Global Prosperity. Keynote Address ABIC '98 Conference: "Biotechnology-The Science of Success", Saskatoon, Canada, ISAAA Briefs 6. The International Service for the Acquisition of Agri-biotech Applications, Ithaca, New York, 1998.

13. Leslie TW, Hoheisel GA, Biddinger DJ, Rohr JR, Fleisher SJ. Transgenes sustain epigeal insect biodiversity in diversified vegetable farm systems. Env. Entom. 2007; 36:234-244.

14. Liu S, Hu Y, Wang X, Zhong J, Lin Z. High content of resveratrol in lettuce transformed with a stilbene synthase gene of Partenocissushenryana. J Agr. Food Chem.2006; 54:8082-8085.

15. Monsanto. Supplemental toolkit for investors, Updated. Monsanto, 2011.

16. Morris J, Hawthorne KM, Hotze T, Abrams, SA Hirschi KD. Nutritional impact of elevated calcium transport activity in carrots. Proc. Natl. Acad. Sci., (USA). 2008; 105:1431-1435.

17. Ortiz R, Smale M. Transgenic crops: pro-poor or prorich? Chronica Hort. 2007; 47(4):9-12.

18. Park S, Kim CK, Pike LM, Smith RH, Hirschi KD. Increased calcium in carrots by expression of an Arabidopsis $\mathrm{H}+/ \mathrm{Ca} 2+$ transporter. Mol. Breed. 2004; 14:275-282.

19. RaoS, Yajnik CS, Kanade A, Fall DHD, Margetts BM, Jackson AA. Intake of micronutrient-rich foods in rural Indian mothers is associated with the size of their babies at birth: Pune maternal nutrition study. J Nutrition. 2001; $131: 1217-1224$.

20. Schultheis JR, Walters SA. Yield and virus resistance of summer squash cultivars and breeding lines in North Carolina. Hort Science. 1998; 8:31-39.

21. Shankula S. Quantification of the Impacts on US Agriculture of Biotechnology-Derived Crops Planted in,2006.http://www.ncfap.org/. 
22. Singh S, Kumar R, Singh A, Singh LB, Yadav S, Kumar J. Transgenic Research in Horticultural Crops an Overview. Chemical Science Review and Letters. 2017; 6(22):1010-1017.

23. Wrubel RP, Gressel J. Are herbicide mixtures useful for delaying the rapid evolution of resistance? A case study. Weed Techn. 1994; 8:635-648.

24. Zuo X, Zhang Y, Wu B, Chang X, Ru B. Expression of the mouse metallothionein mutant b-cDNA in the lettuces (Lactuca sativa L.). Chinese Sci. Bull. 2002; 47:558-562. 